\title{
Response of Two Local Common Bean Ecotypes of "Fagioli di Sarconi" PGI (Phaseolus vulgaris L.) to Seed-Borne Pathogens and Environmental Change
}

\author{
Antonella Vitti ${ }^{1,2, * \mathbb{D}}$, Vincenzo Bevilacqua ${ }^{1}$, Giuseppina Logozzo ${ }^{1}$, Stefania Marzario ${ }^{1}$, Tania Gioia ${ }^{1, * \mathbb{D}}$ \\ and Maria Nuzzaci ${ }^{1}$ (D) \\ 1 School of Agricultural, Forestry and Environmental Sciences, University of Basilicata, \\ Viale dell'Ateneo Lucano 10, 85100 Potenza, Italy; vincenzogiovann1984@libero.it (V.B.); \\ giuseppina.logozzo@unibas.it (G.L.); stefy.85s@libero.it (S.M.); maria.nuzzaci@unibas.it (M.N.) \\ 2 Pharmacy Department, University of Salerno, Via Giovanni Paolo II n.132, 84084 Fisciano, Italy \\ * Correspondence: avitti@unisa.it (A.V.); tania.gioia@unibas.it (T.G.)
}

check for

updates

Citation: Vitti, A.; Bevilacqua, V.; Logozzo, G.; Marzario, S.; Gioia, T.; Nuzzaci, M. Response of Two Local Common Bean Ecotypes of "Fagioli di Sarconi" PGI (Phaseolus vulgaris L.) to Seed-Borne Pathogens and Environmental Change. Agronomy 2021, 11, 1924. https://doi.org/ 10.3390/agronomy11101924

Academic Editor: Katja Witzel

Received: 13 August 2021

Accepted: 22 September 2021

Published: 25 September 2021

Publisher's Note: MDPI stays neutral with regard to jurisdictional claims in published maps and institutional affiliations.

Copyright: (c) 2021 by the authors. Licensee MDPI, Basel, Switzerland. This article is an open access article distributed under the terms and conditions of the Creative Commons Attribution (CC BY) license (https:// creativecommons.org/licenses/by/ $4.0 /)$.

\begin{abstract}
Among foods protected by the European Union with the PGI (Protected Geographical Indication) mark, several ecotypes of "Fagioli di Sarconi" common beans, typical legumes of Basilicata Region, are included. This work aimed to conduct a survey of seed-borne pathogens isolated from "Ciuoto" and "Cannellino rosso", ecotypes of "Fagioli di Sarconi" common beans, in two years and cultivation areas of the National Park of the Agri Valley, for identifying resistant and climatic changes well-adapted genotypes. Three validated methods were used for the seed-borne pathogens screening. Eighteen fungi were differently found for ecotype and year of observation by the washing test. Saprophyte contaminants pathogens isolated and detected by the blotter test were strongly reduced by $1 \%$ sodium hypochlorite treatment. Using the between paper test, specific for detecting Colletotrichum lindemuthianum, the presence of this pathogen for both ecotypes, years and cultivation areas, and also some bacteria were individuated. Therefore, area-, environment- and ecotypedependent differences were revealed, probably also caused by a different polyphenolic content and thickness of integument of two ecotypes. This study represents a baseline information for further studies, development of forecasting models and management of seed-borne diseases associated with common beans.
\end{abstract}

Keywords: PGI (Protected Geographical Indication) marked common bean; "Ciuoto" and "Cannellino rosso" ecotypes; indigenous Trichoderma spp.; genotypes resistance

\section{Introduction}

Phaseolus vulgaris L., known as common bean, is the second most important legume in the world for food purposes thanks to its high nutritional value in terms of content of protein, vitamins, zinc, iron, and fiber [1-3]. It is widespread over a large area between $52^{\circ} \mathrm{N}$ and $32^{\circ} \mathrm{S}$ latitude, at low altitudes until sea level (USA and Europe) and high altitude (South America) [4-6]. In Italy, the cultivated area is 22,501 ha $(17,161$ and 5340 ha for green and dry beans, respectively); the Basilicata Region (South Italy) is invested with 125 ha of dry beans [7]. "Fagioli di Sarconi" common beans include about 21 different ecotypes protected by the European Union (Commission Regulation (EC) No 1263/96) with the mark PGI (Protected Geographical Indication). These legumes are used as a prevalent healthy food in Italian cuisine, and are cultivated in the National Park of the Agri Valley in Basilicata for dry seed production [8-10].

The "Consorzio di Tutela dei Fagioli di Sarconi" has preserved the germplasm on farm and its biochemical and nutraceutical traits have been characterized [5,8-16]; however, research on the response to diseases of common bean ecotypes is limited [17]. 
Seed-borne pathogenic fungi and bacteria can inhibit germination, infect the seedlings to death, or reduce plant growth by damaging the roots and vascular system, and affecting the transport of water and nutrients [17-20].

The main seed-borne pathogenic fungi that cause losses of yield and quality of common bean are Alternaria spp. Aspergillus spp., Penicillium spp., Fusarium spp., Colletotrichum lindemuthianum (Sacc. \& Magnus) Briosi \& Cav, Botrytis spp., Rhizopus spp., Cladosporium spp., Rhizoctonia solani (Cooke) Wint [19-24]. All these fungi are seed-transmitted and can be preserved in the form of conidia in the coat or as mycelia on the seed surface [25], at extra- or intra-embryal level, or associated with the seeds as contaminants [26]. For this reason, all these fungi represent a limiting factor for common bean production in many countries.

According to the classic disease triangle, the host-pathogen-environment interactions are the cause of plant disease occurrence and severity [27]. Therefore, the environment has been always considered an important ring in plant pathology studies. Currently, climate change is strongly associated with seed-borne fungally induced disease incidence and severity. In fact, climate changes influence the growth, reproduction, survival, spread, pathogenicity, as well as the ability to modify a typical soil microflora, enabling the emergence of new species [28,29].

In this context, this study aimed to determine the influence of different cultivation areas on the presence of seed-borne pathogens isolated from seeds of two ecotypes of "Fagioli di Sarconi" common beans, "Ciuoto" and "Cannellino rosso", collected from two different cultivation areas of the Basilicata Region during the years 2018 and 2019, for the identification of genotypes resistant or little susceptible to seed-borne pathogens and well adapted to environmental changes.

\section{Materials and Methods}

\subsection{Sample Collection}

During the years 2018 and 2019, the phytosanitary status of seeds of two ecotypes of "Fagioli di Sarconi" PGI common bean, "Ciuoto" and "Cannellino rosso", characterized by a determinate growth habit (class 1) [30], was evaluated. The populations were multiplied in organic farms, in two different areas located in the National Park of the Agri Valley: Sarconi (latitude, $40^{\circ} 15^{\prime} 54^{\prime \prime} \mathrm{N}$; longitude, $15^{\circ} 54^{\prime} 43^{\prime \prime}$ E; altitude, $620 \mathrm{~m}$ a.s.l.) and Paterno (latitude, $40^{\circ} 20^{\prime} 25^{\prime \prime} \mathrm{N}$; longitude, $15^{\circ} 46^{\prime} 03^{\prime \prime} \mathrm{E}$; altitude, $595 \mathrm{~m}$ a.s.l.), Potenza, Italy. In both locations, soil is a fertile coarse lime soil, suitable for bean cultivation. Ecotype seeds were manually sown in rows ( $0.5 \mathrm{~m}$ between rows; $0.10 \mathrm{~m}$ between plants) during the first decade of June and harvested during the first decade of November, in each farm and in each location. Standard organic agronomic management and irrigation practices were applied to the experimental fields. After the manual harvesting and ginning of pods, all seeds collected were placed in plastic sterile bags and transported in cooler bags to the laboratories. The samples were immediately used for the following analyses.

Seed color types were detected by visual inspection, according to bean seed imaging from Basic Protocol 2 [31], for future quality control and postprocessing. As reported in Figure 1 and Table 1, "Ciuoto" and "Cannellino rosso" have different seed qualitative and quantitative morphological traits.

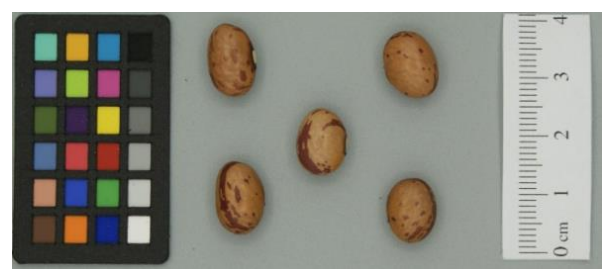

(a)

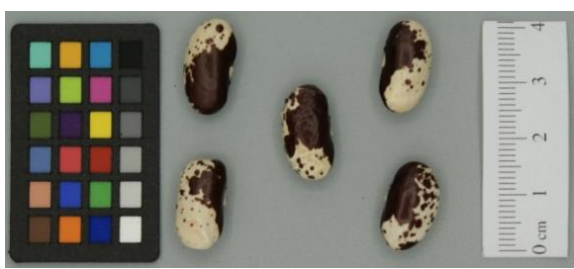

(b)

Figure 1. Common bean seed ecotypes of "Fagioli di Sarconi" PGI (Protected Geographical Indication): “Ciuoto" (a) and "Cannellino rosso" (b). 
Table 1. Common bean seed traits in "Fagioli di Sarconi" PGI (Protected Geographical Indication) ecotypes used in the present study.

\begin{tabular}{|c|c|c|c|c|c|c|c|}
\hline \multirow{2}{*}{$\begin{array}{l}\text { Fagioli di Sarconi } \\
\text { PGI Ecotype }\end{array}$} & \multicolumn{7}{|c|}{ Seed Qualitative Trait } \\
\hline & $\begin{array}{c}\text { Coat Darker } \\
\text { Color }\end{array}$ & $\begin{array}{l}\text { Coat Lighter } \\
\text { Color }\end{array}$ & Coat Patter & $\begin{array}{l}\text { Longitudinal } \\
\text { Shape }\end{array}$ & $\begin{array}{l}\text { Transverse } \\
\text { Shape }\end{array}$ & Veining & Brilliance \\
\hline Ciuoto & Cream/Brown & Purple/red & Stripe & Oval & Large elliptic & Weak & Medium \\
\hline Cannellino rosso & Whitish & Purple & $\begin{array}{l}\text { Spotted } \\
\text { bicolor }\end{array}$ & $\begin{array}{l}\text { Kidney } \\
\text { shaped }\end{array}$ & Elliptic & Weak & Medium \\
\hline \multirow{2}{*}{$\begin{array}{l}\text { Fagioli di Sarconi } \\
\text { PGI ecotype }\end{array}$} & \multicolumn{7}{|c|}{ Seed Quantitative Trait } \\
\hline & Length (mm) & \multicolumn{2}{|c|}{ Height (mm) } & \multicolumn{2}{|c|}{ Width (mm) } & \multicolumn{2}{|c|}{ Weight (g) } \\
\hline Ciuoto & $11.13 \pm 1.02$ & \multicolumn{2}{|c|}{$7.54 \pm 0.62$} & \multicolumn{2}{|c|}{$6.53 \pm 0.55$} & \multicolumn{2}{|c|}{$0.38 \pm 0.08$} \\
\hline Cannellino rosso & $15.91 \pm 0.81$ & \multicolumn{2}{|c|}{$8.09 \pm 0.49$} & \multicolumn{2}{|c|}{$6.54 \pm 0.48$} & \multicolumn{2}{|c|}{$0.63 \pm 0.09$} \\
\hline
\end{tabular}

Data are expressed as the mean of 25 seeds for each lot \pm SDs.

The two locations are in an internal intensive horticultural area, characterized by a temperate Mediterranean climate with cool winters and warm dry summers. The data of maximum, minimum and average temperature and rainfall for the growing season (June to November 2018 and 2019) were obtained from the nearest weather station, the agrometeorological station of the Agenzia Lucana per lo Sviluppo e l'Innovazione in Agricoltura (ALSIA) of the Basilicata Region located about 8 and $14 \mathrm{~km}$ from Paterno's and Sarconi's farm, respectively.

\subsection{Isolation of Seed Microflora}

The phytopathological analysis of seeds was carried out with three different methods $[32,33]$.

\subsubsection{Washing Test}

For each test, 400 seeds ( 4 replicates $\times 100$ ) were considered, according to [32], with some modifications. The separation of spores and mycelium from the integument surface was obtained by stirring the seeds in presence of sterile, distilled water. After filtration, the suspension was centrifuged at $5000 \times g$ for $11 \mathrm{~min}$. The precipitate was resuspended in $200 \mu \mathrm{L}$ sterile, distilled water, and samples were set up for observation under the optical microscope. In addition to this procedure, seeds were sown on Petri dish containing Potato Dextrose Agar (PDA) and the antibiotics ampicillin and stremptomycin (Sigma-Aldrich, Italy), and incubated at $22{ }^{\circ} \mathrm{C}$ in the dark, for 5-8 days. Then afterwards, slides were prepared for observation under the optical microscope.

\subsubsection{Blotter Test}

According to [32], with some modifications, filter paper discs were placed in $140 \mathrm{~mm}$ diameter Petri dishes and moistened with $2 \mathrm{~mL}$ of sterile, distilled water. Four hundred seeds ( 4 replicates $\times 100$ ) were treated with a $1 \%$ sodium hypochlorite solution for $10 \mathrm{~min}$ and distributed on the moistened paper. The dishes were incubated at $20^{\circ} \mathrm{C}$ for 10 days, alternating $12 \mathrm{~h}$ of $380 \mathrm{~nm}$ NUV-light (near-UV-light) tubes and $12 \mathrm{~h}$ of dark. After the incubation, the seeds were examined under the optical microscope. Untreated seeds represented the control.

\subsubsection{Between Paper Test}

The identification and subsequent characterization of Colletotrichum spp. was carried out on 200 seeds (4 replicates $\times 50$ ) according to [33], with small modifications. After seeds disinfection and air-drying, 4 sub-samples of 50 seeds were placed between two double sheets of toweling paper and soaked in sterile distilled water. The paper toweling was folded lengthwise and covered with a polyethylene sheet to keep a high moisture during incubation $\left(7\right.$ days at $\left.20^{\circ} \mathrm{C}\right)$. Then, the seeds and cotyledons were observed, and 
black depressed areas with well-defined contours were searched. The typical signs of the anthracnose presence were visually and under optical microscope checked (acervules with or without bristles).

\subsection{Identification of Pathogens}

After the incubations and the preparation of slides, the macroscopic (appearance of the colony and mycelium) and microscopic (appearance of the mycelium, presence or absence of septa in hyphae, color, shape and size of conidia, reproductive structures) characteristics were revealed under the optical microscope (Axioskop, Zeiss, Jena, Germany) at 20×, 40×, $60 \times$ and $100 \times$ resolution. For the microscopic and morphological identification of the fungal isolates, the scientific literature and mycological atlases with related taxonomic keys were used [34-42].

\subsection{Disease Assessment}

Seed disease incidence caused by the seed-borne fungi (R. solani, F. oxysporum, C. lindemuthianum) and bacteria (Pseudomonas syringae pv. phaseolicola and Xanthomonas campestris pv. phaseoli) was examined 14 days post-germination using the scores 0-heathy and 1infected. Disease incidence was obtained by dividing the number of infected seeds by total number of seeds and then multiplying by 100 .

\subsection{Statistical Analysis}

Meteorological parameters (precipitation, minimum, maximum and average temperature, minimum, maximum and average relative humidity and potential evapotranspiration) for the two years of observation 2018 and 2019 were analyzed with SAS OnDemand for Academics (SAS Institute, Inc., Cary, NC, USA) [43] by proc ANOVA (one-way analysis of variance). The statistical data on disease were performed using $R$ Stats Package (Version 4.0.2 (2020-06-22); R Core Team, 2020) using the RStudio environment (Version 1.3.1093; RStudio Team, 2020) [44] by Pearson's chi-squared test.

\section{Results}

\subsection{Meteorological Parameters}

The rain, temperature and relative humidity data for the Agri Valley territory during the cultivation period, from June to November for both years 2018 and 2019, are summarized in Table 2 and in Figure 2.

Table 2. Meteorological parameters provided by the ALSIA agro-meteorological station in the Agri Valley for the two years of observation, 2018 and 2019.

\begin{tabular}{|c|c|c|c|c|c|c|c|c|c|}
\hline \multirow{2}{*}{ Meteorological Parameter } & \multicolumn{4}{|c|}{2018} & \multicolumn{4}{|c|}{2019} & \multirow[t]{2}{*}{$p r(>\mathrm{F})$} \\
\hline & Min & Max & Range & Mean & Min & Max & Range & Mean & \\
\hline Rain $\left(\mathrm{mm}\right.$ day $\left.^{-1}\right)$ & 0.00 & 38.60 & 38.60 & 2.09 & 0.00 & 56.40 & 56.40 & 1.69 & 0.530 \\
\hline \multicolumn{10}{|l|}{ Temperature air $\left({ }^{\circ} \mathrm{C}\right.$ day $\left.^{-1}\right)$} \\
\hline Minimum & -4.30 & 19.80 & 24.10 & 10.03 & -0.50 & 16.50 & 17.00 & 9.58 & 0.301 \\
\hline Maximum & 8.40 & 36.40 & 28.00 & 26.13 & 11.00 & 39.40 & 28.40 & 27.78 & $0.016 *$ \\
\hline Average & 2.83 & 25.78 & 22.94 & 17.20 & 6.28 & 25.93 & 19.64 & 18.08 & 0.094 \\
\hline \multicolumn{10}{|l|}{ Relative humidity $\left(\%\right.$ day $^{-1}$ ) } \\
\hline Minimum & 19.00 & 90.00 & 71.00 & 42.39 & 13.00 & 91.00 & 78.00 & 37.58 & $0.001^{* * *}$ \\
\hline Maximum & 67.80 & 100.00 & 32.20 & 96.96 & 82.00 & 99.80 & 17.80 & 96.96 & 0.998 \\
\hline Average & 46.25 & 96.42 & 50.17 & 75.09 & 49.67 & 96.79 & 47.13 & 71.25 & $0.000 * * *$ \\
\hline Evapotranspiration $\left(\mathrm{mm} \mathrm{day}^{-1}\right.$ ) & 0.76 & 8.13 & 7.37 & 4.44 & 0.90 & 8.08 & 7.18 & 4.87 & $0.049 *$ \\
\hline
\end{tabular}




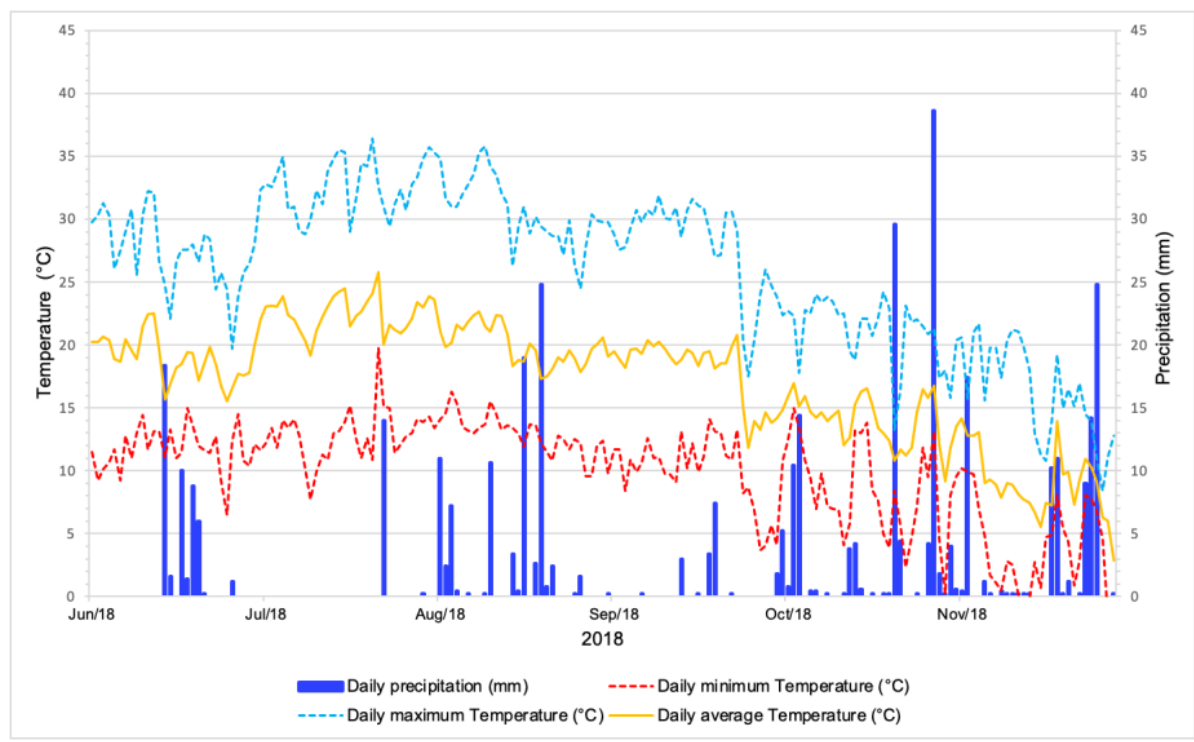

(a)

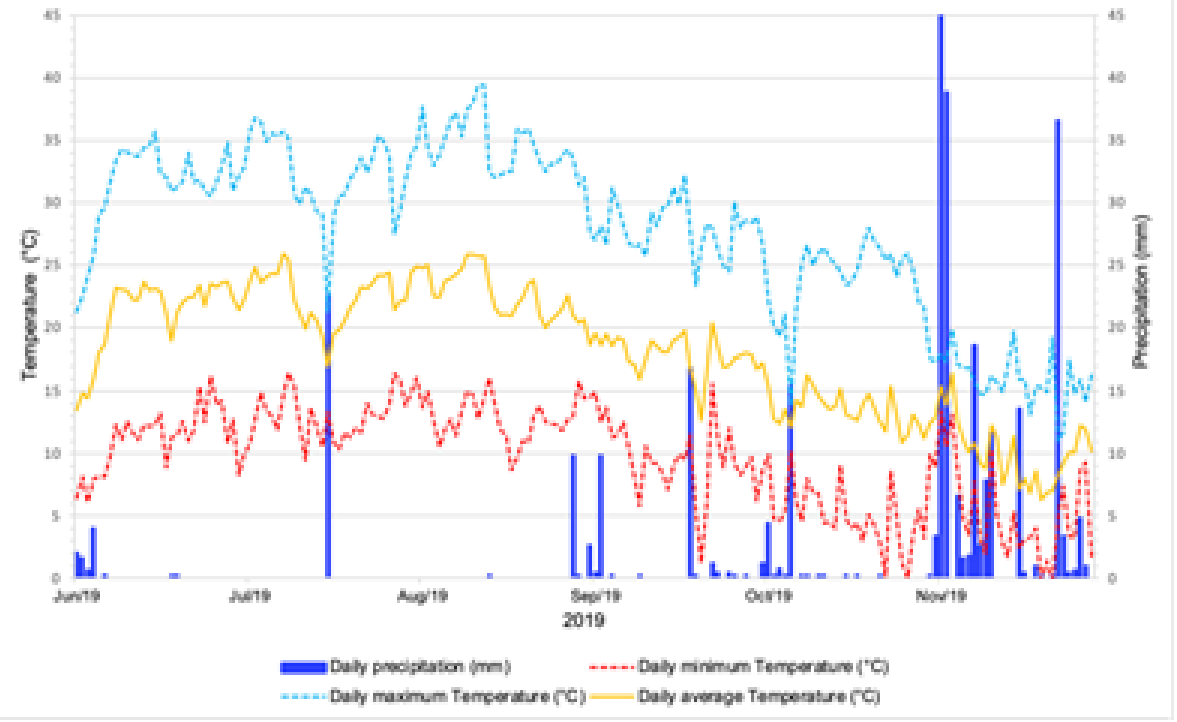

(b)

Figure 2. Total precipitation and minimum, maximum and average temperatures during the bean growing seasons of June-November 2018 (a) and 2019 (b).

During the 2019 cultivation cycle the average daily rainfall, equal to $1.69 \mathrm{~mm} \mathrm{day}^{-1}$, was lower than the previous year $\left(2.09 \mathrm{~mm} \mathrm{day}^{-1}\right)$, but was not significantly different. Regarding the temperatures, only the maximum showed a significantly different value between the two years. In the same way, the minimum and average relative humidity were significantly different between the two years, with values in 2019 being lower than in the previous year. As a consequence, the average evapotranspiration during 2019 was significantly higher with respect to 2018 .

\subsection{Isolation and Identification of Seed Mycoflora by Washing Test}

Eighteen seed-borne fungal species were found contaminating or infecting the two ecotypes of "Fagioli di Sarconi" PGI common bean seeds in the two different areas and during the two years 2018 and 2019 (Table 3). 
Table 3. Seed-borne fungal species isolated and detected $(+)$ or not $(-)$ by washing test on the two ecotypes of "Fagioli di Sarconi" PGI common bean seeds.

\begin{tabular}{|c|c|c|c|c|c|c|c|c|}
\hline \multirow{3}{*}{$\begin{array}{l}\text { Ecotype } \\
\text { Locality }\end{array}$} & \multicolumn{4}{|c|}{2018} & \multicolumn{4}{|c|}{2019} \\
\hline & \multicolumn{2}{|c|}{ Ciuoto } & \multicolumn{2}{|c|}{ Cannellino Rosso } & \multicolumn{2}{|c|}{ Ciuoto } & \multicolumn{2}{|c|}{ Cannellino Rosso } \\
\hline & Sarconi & Paterno & Sarconi & Paterno & Sarconi & Paterno & Sarconi & Paterno \\
\hline \multicolumn{9}{|l|}{ Fungal microflora } \\
\hline Alternaria spp. & + & - & - & - & - & + & + & - \\
\hline Alternaria alternata & - & - & - & - & - & + & - & + \\
\hline Aspergillus spp. & - & - & + & + & - & - & - & - \\
\hline Aspergillus flavus & - & - & + & + & + & - & - & - \\
\hline Aspergillus niger & + & - & - & - & - & - & + & - \\
\hline $\begin{array}{l}\text { Cladosporium } \\
\text { cladosporioides }\end{array}$ & - & - & - & + & + & + & + & - \\
\hline Botritys spp. & - & - & + & - & - & + & - & + \\
\hline $\begin{array}{l}\text { Colletotrichum } \\
\text { lindemuthianum }\end{array}$ & - & + & - & - & - & + & - & - \\
\hline Fusarium oxysporum & - & - & - & - & - & + & - & + \\
\hline Fusarium solani & - & + & - & - & - & + & - & - \\
\hline Mucor hiemalis & + & - & - & - & - & - & + & - \\
\hline Penicillium spp. & - & - & + & + & - & + & + & + \\
\hline Penicillium expansum & - & + & - & - & - & + & - & - \\
\hline Rhizoctonia solani & - & + & - & + & + & + & + & + \\
\hline Rhizophus nigricans & + & - & - & - & - & - & - & - \\
\hline Trichoderma harzianum & - & - & - & + & - & - & - & - \\
\hline Tricoderma viridae & + & - & - & - & - & - & - & - \\
\hline Uromyces appendiculatus & - & - & - & - & - & + & - & + \\
\hline
\end{tabular}

Data from [45].

Microscopic morphological structures identifying the fungi Rhizoctonia solani isolated from "Cannellino rosso" ecotype in Paterno (2018), Colletotrichum lindemuthianum and Fusarium oxysporum isolated from "Ciuoto" in 2019 in Paterno and Sarconi, respectively, are shown in Figure 3. In particular, Figure 3a shows the typical durable moniloid cells of R. solani; the conidia of C. lindemuthianum showed in Figure $3 b$ are typically cylindrical, fusiform or sickle-shaped, hyaline with smooth wall and with two guttules; the macroconidia of F. oxysporum were individuated by their typical three to five septa, the apical and basal cells being moderately curved and foot shaped, respectively, while the microconidia for their drop shape were without septa (Figure 3c).

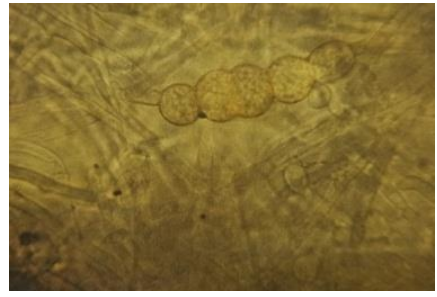

(a)

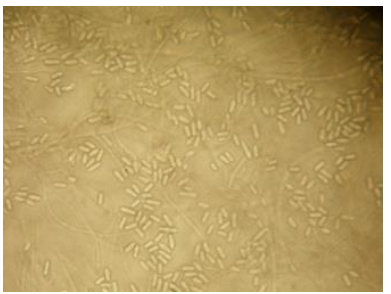

(b)

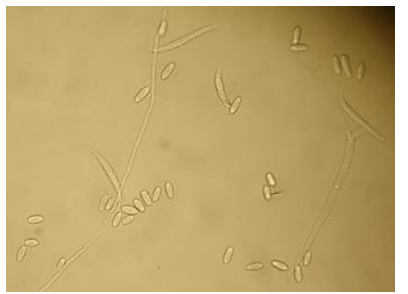

(c)

Figure 3. (a) Moniloid cells of $R$. solani (resolution $60 \times$ ); (b) conidia of C. lindemuthianum (resolution 20×); (c) macroconidia and microconidia of F. oxysporum (resolution $40 \times$ ).

3.3. Identification and Incidence of R. solani on Treated and Untreated Seeds with Blotter Test, and of C. lindemuthianum, F. oxysporum and Bacterial Diseases Causal Agents with between Paper Test

The blotter test was able to identify, in the $1 \%$ sodium hypochlorite treated seeds, the following seed-borne fungi: $R$. solani (both years, ecotypes and localities); Aspergillus niger 
(2018, Paterno, both ecotypes; 2019, Sarconi, “Cannellino rosso”); F. solani (2019, Paterno, both ecotypes); Penicillium expansum (2018, Paterno, "Ciuoto").

On the other hand, the following fungi were detected in untreated seeds: Aspergillus flavus (2019, Sarconi, "Cannellino rosso"); A. niger (2018, Paterno, both ecotypes; 2019, Sarconi, both ecotypes); Cladosporium cladosporioides (2019, Sarconi, "Cannellino rosso"); F. solani (2018, Paterno, "Ciuoto"; 2019, Paterno, "Cannellino rosso"); Mucor hiemalis (2018, Sarconi, "Ciuoto" and Paterno, both ecotypes; 2019, Paterno, both ecotypes); Penicillium spp. (2018, Sarconi, “Cannellino rosso"); P. expansum (2018, Paterno, “Ciuoto"); Rhizophus nigricans (2018, Sarconi, "Ciuoto").

With the between paper test, although specific for C. lindemuthianum, the fungus $F$. oxysporum and two bacterial diseases causal agents were isolated and detected, as reported in Table 4.

Table 4. Seed-borne fungal and bacterial species isolated detected $(+)$ or not $(-)$ by blotter and between paper tests on the two ecotypes of "Fagioli di Sarconi" PGI common bean seeds. The percentage of disease incidence indicates rhizoctoniosis from $R$. solani and the presence of typical fungal or bacterial symptoms for the other pathogens.

\begin{tabular}{|c|c|c|c|c|c|c|c|c|}
\hline \multirow{3}{*}{$\begin{array}{c}\text { Year } \\
\text { Ecotype } \\
\text { Locality }\end{array}$} & \multicolumn{4}{|c|}{2018} & \multicolumn{4}{|c|}{2019} \\
\hline & \multicolumn{2}{|c|}{ Ciuoto } & \multicolumn{2}{|c|}{ Cannellino Rosso } & \multicolumn{2}{|c|}{ Ciuoto } & \multicolumn{2}{|c|}{ Cannellino Rosso } \\
\hline & Sarconi & Paterno & Sarconi & Paterno & Sarconi & Paterno & Sarconi & Paterno \\
\hline \multicolumn{9}{|c|}{ Blotter Method } \\
\hline Rhizoctonia solani & & & & & & & & \\
\hline treated seed & + & + & + & + & + & + & + & + \\
\hline Disease incidence $(\%)^{1}$ & 27 & 23 & 8 & 15 & 12 & 15 & 4 & 8 \\
\hline untreated seed & + & + & + & + & + & + & + & + \\
\hline Disease incidence $(\%)^{1}$ & 19 & 35 & 24 & 27 & 11 & 23 & 12 & 24 \\
\hline \multicolumn{9}{|c|}{ Between Paper Test } \\
\hline Fusarium oxysporum & + & + & - & + & - & + & - & + \\
\hline Disease incidence $(\%)^{2}$ & 1 & 4 & 0 & 2 & 0 & 10 & 0 & 6 \\
\hline C. lindemuthianum & + & + & + & + & + & + & + & + \\
\hline Disease incidence $(\%)^{2}$ & 4 & 40 & 8 & 20 & 4 & 65 & 4 & 30 \\
\hline \multicolumn{9}{|c|}{ Bacterial disease causal agents } \\
\hline P. syringae pv. phaseolicola & + & + & + & + & + & + & + & - \\
\hline X. campestris pv. phaseoli & + & + & + & - & - & + & - & + \\
\hline Disease incidence $(\%)^{2}$ & 28 & 30 & 18 & 24 & 12 & 12 & 6 & 16 \\
\hline
\end{tabular}

${ }^{1}$ The differences of rhizoctoniosis from $R$. solani between untreated and treated seeds are significant for $\chi^{2}=87.04$, at $p<0.0001{ }^{2}$ the differences of symptoms between ecotype, year and locality are significant for $\chi^{2}=9.71$, at $p \leq 0.046$ for $C$. lindemuthianum, for $\chi^{2}=8.50$, at $p<0.037$ for F. oxysporum, and for $\chi^{2}=10.84$, at $p \leq 0.028$ for the bacterial disease. Data from [45].

The seed-borne pathogenic fungi and bacteria considered the most dangerous in determining losses of yield and quality in the common bean were deeply considered in terms of their disease. The percentage of rhizoctoniosis from $R$. solani, as well as the presence of typical symptoms on integument and cotyledons induced by C. lindemuthianum, F. oxysporum and bacterial diseases causal agents are depicted (Table 4).

$R$. solani was detected in both ecotypes and years. The incidence of rhizoctoniosis in common bean seeds treated with hypochlorite for both years was higher for "Ciuoto" with respect to the "Cannellino rosso" ecotype in both Paterno and Sarconi. On the other hand, during the year 2019, the rhizoctoniosis incidence for all treated seeds decreased.

Conversely, R. solani induced a higher disease incidence in the untreated seeds, in both ecotypes and years of cultivation, in the Paterno area.

As showed in Table $4, \chi^{2}$ test indicated differences between ecotype, year and cultivation area for the incidence of fusarium disease as highly significant. The highest incidence of phytopathy was recorded in 2019 for "Ciuoto" in the Paterno area. In Sarconi, in the same year, the presence of fusariosis on seed was not found. 
The incidence of anthracnose symptoms from C. lindemuthianum was evaluated on integument and cotyledons by between paper test. The differences between ecotype, year and area were highly significant, as shown by $\chi^{2}$ test. In particular, for this pathogen, the Paterno area was the most infected one, with the year 2019 being more serious than the previous year and "Cannellino rosso" showing less susceptibility to anthracnose than the "Ciuoto" ecotype.

In summary, the treatment of the seeds with $1 \% \mathrm{Na}$-hypochlorite allowed a reduction of most fungal microflora adhering to the seed, such as Aspergillus flavus, but did not eliminate the systemic pathogens infecting the internal structures of the seed, such as C. lindemuthianum, F. solani, and R. solani.

Furthermore, the different environmental factors in the two years and cultivation areas determined a different incidence of the considered diseases

\subsection{Macroscopic and Microscopic Characterization of R. solani, C. lindemuthianum and F. oxysporum}

The typical damping-off symptoms of R. solani on the stem of the "Cannellino rosso" common bean ecotype, located in Sarconi (2019) and "Ciuoto", and located in Paterno (2018), as revealed by blotter test, are shown in Figure $4 a$,b.

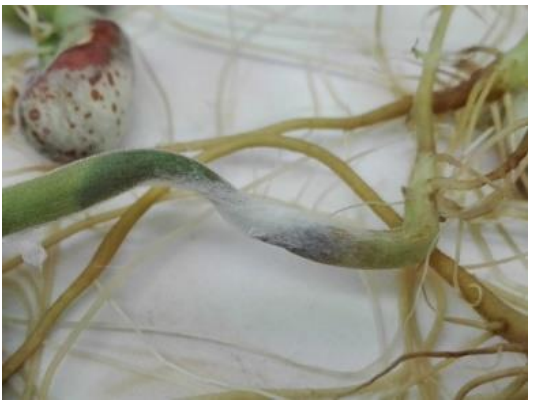

(a)

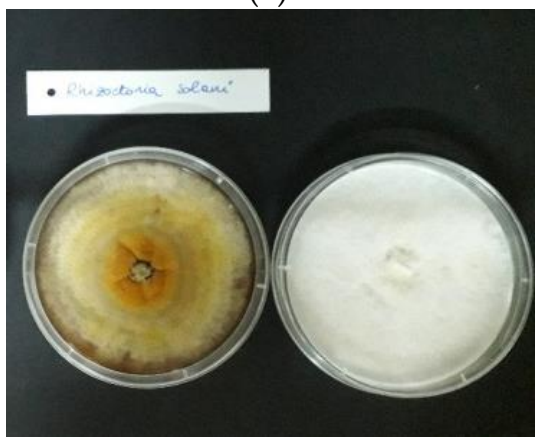

(c)

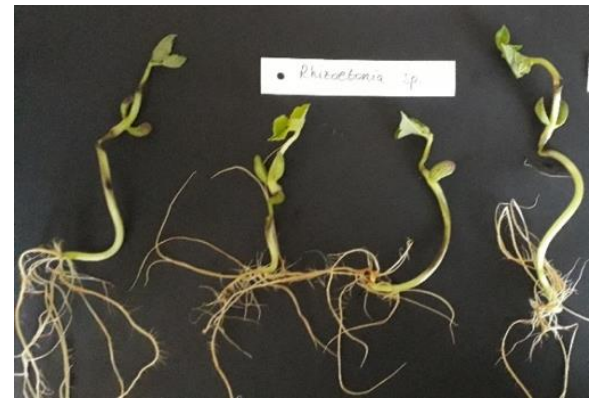

(b)

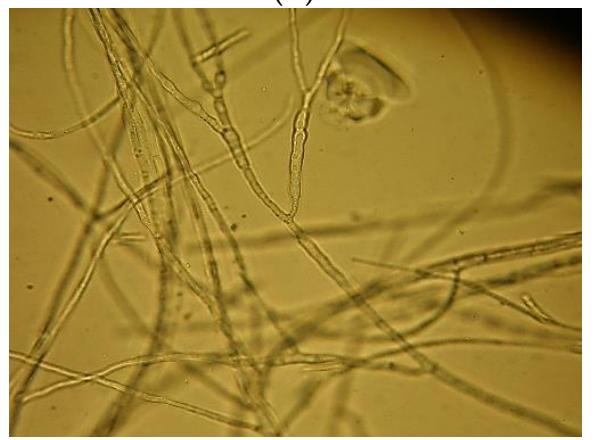

(d)

Figure 4. Symptoms, macroscopic and microscopic characters of R. solani: (a) hydropic halo and felted mycelium, wrapped in a ring on the stem of a "Cannellino rosso" ecotype seedling (data from [45]); (b) collar and root rot symptoms on "Ciuoto" ecotype; (c) different macroscopic mycelium characteristics of the fungus isolated on "Cannellino rosso" ecotype; (d) fungal branching arranged at acute-right angle and restricted in their insertion point (resolution $40 \times$ ).

Figure 4c clearly shows binucleated $R$. solani isolates with considerable morphological variability from white to creamy-yellow, with a felty appearance for the white mycelium, while a daily growth rings with variable tonality in the other. The conidiophores branches of the $R$. solani isolates resulted fold in the direction of growth and slightly narrowed at the point of insertion on main hypha; moreover, the secondary conidiophore branches reached right-acute angles on the main hypha at maturity (Figure $4 \mathrm{~d}$ ).

Figure 5a reports typical anthracnose symptoms on seeds detected by between paper test as spots, more or less wide, and surrounded by a purple halo, as well as some macro- 
scopic and microscopic morphological structures identified as the fungus $C$. lindemuthianum isolated from "Ciuoto" ecotype, located in Paterno (2018).

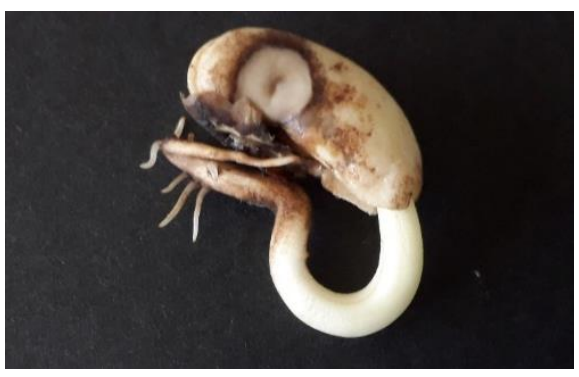

(a)

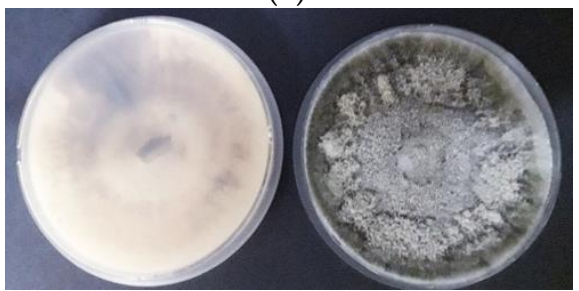

(c)

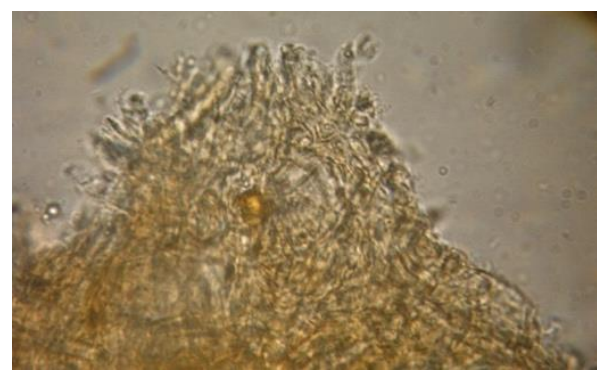

(b)

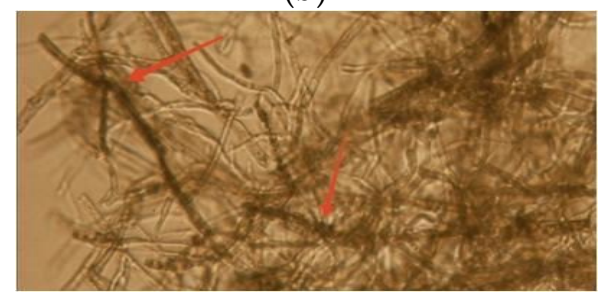

(d)

Figure 5. Symptoms, macroscopic and microscopic characters of $C$. lindemuthianum: (a) symptoms of anthracnose on integuments and cotyledons of "Ciuoto" ecotype located in Paterno (2018); (b) acervulus similar to sporodochium from seeds, with bristles in evidence (resolution 20×); (c) macroscopic mouse-grey colored aerial mycelium characteristic of the fungus; (d) detail of acervulus similar to sporodochium from plates, with subulate, terminal and septate bristles in evidence, where the red arrow indicates their basal portion (resolution $100 \times$ ).

C. lindemuthianum is a mitosporic fungus with four physiological breeds known to have different degrees of pathogenicity compared to common bean cultivars. Colonies are from salmon-gray to mouse-gray in color, as shown in our isolates (Figure 5c), and produce acervules consisting of a compact layer of cylindrical, hyaline, curved, pigmented phialides (Figure $5 b$ ). The typical acervules of $C$. lindemuthianum with dark, scattered, 5-9 septate and pigmented bristles are depicted in Figure $5 \mathrm{~d}$.

The morphological characteristics of F. oxysporum are reported in Figure 6. Typical rot seeds were revealed, characterized by the presence of abundant aerial, white, felty, flaky with a purplish central mass mycelium, as also confirmed by the macroscopic appearance of the colonies on the plate (Figure $6 a, b)$. The macroconidia were slightly curved, with three to five septa, and hooked basal and short apical cells, as is typical of this fungus; even the microconidia appeared to be typically formed at the end of the phialidia, and were abundant, fusiform, reniform, and produced by branched polyphialides (Figure 6c).

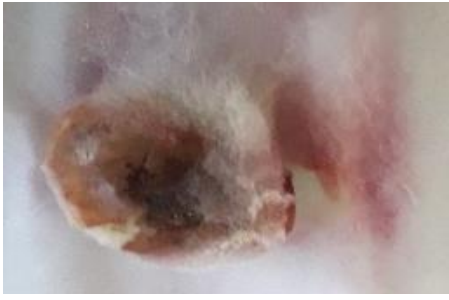

(a)

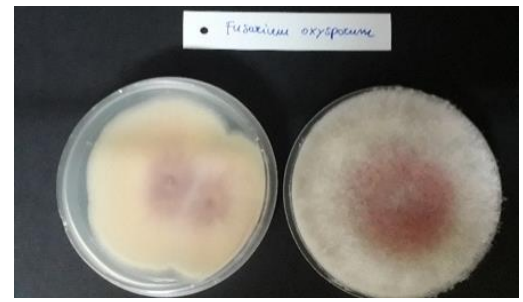

(b)

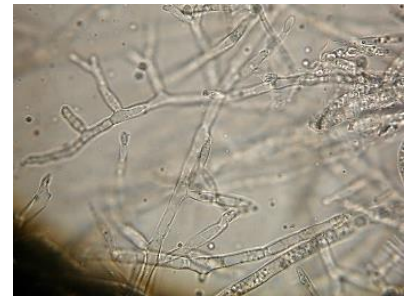

(c)

Figure 6. Symptoms, macroscopic and microscopic characteristics of F. oxysporum: (a) mycelium on the integument, with a characteristic vinous aura, on "Ciuoto" ecotype seed, located in Paterno (2019); (b) macroscopic mycelium of the fungus with its characteristic dark purple color; (c) fungal conidiophora with branched polyphialids (resolution $100 \times$ ). 


\section{Discussion}

Seed health is a critical factor in achieving a good product and high yields. The presence of pathogens in or on the seed influences all the plant vegetative and productive phases. Seeds intended for food may not only have little nutritional value, they may also be contaminated with mycotoxins. Therefore, the health of the seed is an indispensable requirement for the productivity and quality of the crop. For the isolation and identification of the seed-borne pathogens of common beans, diagnostic methods with different sensitivities were used. The washing test method allows to identify the spores of the fungi contaminating the seed surface $[32,33]$. Therefore, it proved to be the most effective and sensitive compared to the other ones for this purpose. In fact, the washing test made it possible to detect most of the fungi contaminating the integument and infecting the cotyledons and the embryo. There were 18 seed-borne fungal agents. Most of these (R. solani, C. lindemuthianum, F. oxysporum, F. solani, U. appendiculatus) are of great importance due to the damages they cause to the seed in pre- and post-emergence, thus causing economic losses [46]; the other fungal pathogens detected are no less dangerous (Alternaria alternata, Penicillium spp., A. flavus, A. niger, M. hiemalis, Fusarium spp.), and determine substantial problems linked to mycotoxin production during post-harvest storage [16]. This method also made it possible to identify beneficial fungi (T. harzianum and T. viridae) known to be used as antagonists of harmful pathogens [47-49].

The blotter method, unlike the washing test, is more selective towards some pathogens with saprophytic behavior (Aspergillus spp., Cladosporium spp., Botritys spp., Mucor spp., Rhizophus spp.). The treatment of the seeds with $1 \% \mathrm{Na}$-hypochlorite allowed a reduction of most of fungal microflora adhering to the seed, but did not make it possible to eliminate the systemic pathogens infecting the internal structures of the seed, such as $C$. lindemuthianum, F. solani, and R. solani. Nevertheless, the treatment was able to decrease the presence of some conidia and/or mycelia in the coat and on the seed surface, thus decreasing the disease incidence of $R$. solani. The between paper method, applied as international protocol specific for detecting $C$. lindemuthianum, revealed its presence in both ecotypes, years and areas.

Regarding thermo-hygrometric data, collected during the entire crop cycle, the average air temperature was $17.20^{\circ} \mathrm{C}$ in 2018 and $18.08{ }^{\circ} \mathrm{C}$ in 2019 , without significant difference between the two years, while the maximum temperatures, equal to $26.13^{\circ} \mathrm{C}$ and $27.78{ }^{\circ} \mathrm{C}$ during 2018 and 2019 , respectively, were significatively different. This finding could explain the prevalent presence of the mesophilic fungal species detected during the year 2018, when their spores were able to germinate at humidity values of $55-75 \%$, such as Alternaria spp., A. alternata, C. cladosporioides, Penicillium spp., Fusarium spp., Colletotrichum spp., and $R$. solani [38,42].

Temperature plays an important role in sporulation, germination of conidia and in the development of fungal pathogens. Table 5, built taking into account scientific studies investigating the development of the same isolated and identified phytopathogenic fungi in the current study, clearly indicates that they can develop between -5 and $50{ }^{\circ} \mathrm{C}$, with optimal growth around $25^{\circ} \mathrm{C}$.

In particular, fungal species found on the two "Fagioli di Sarconi" PGI common bean ecotypes seeds, belonging to thermophilic fungi (development at maximum temperature of $45-50{ }^{\circ} \mathrm{C}$, and minimum growth temperature not lower than $20^{\circ} \mathrm{C}$ ), were $A$. niger and $M$. hiemalis. The detected mesophilic fungi (development between 10 and $40{ }^{\circ} \mathrm{C}$, with optimum at $25^{\circ} \mathrm{C}$ ) were Alternaria spp., A. alternata, Aspergillus spp., A. flavus, C. lindemuthianum, F. oxysporum, F. solani, R. solani, U. appendiculatus and Trichoderma spp. Finally, C. cladosporioides, Botrytis spp., R. nigricans, Penicillium spp., P. expansum were the detected cryophilic fungi (optimum development between 5 and $10{ }^{\circ} \mathrm{C}$ ). 
Table 5. Referenced temperature ranges $\left({ }^{\circ} \mathrm{C}\right)$ for all isolated seed-borne fungal species.

\begin{tabular}{|c|c|c|c|c|c|c|c|c|c|c|c|c|c|}
\hline \multirow[b]{2}{*}{ Mycoflora } & \multicolumn{12}{|c|}{ Development Temperature $\left({ }^{\circ} \mathrm{C}\right)$} & \multirow[t]{2}{*}{ References } \\
\hline & -5 & 0 & 5 & 10 & 15 & 20 & 25 & 30 & 35 & 40 & 45 & 50 & \\
\hline Alternaria spp. & & & & & & $x$ & $x$ & $\mathrm{x}$ & $x$ & & & & [50] \\
\hline Alternaria alternata (Fr.) Keissler & & & & & & $x$ & $x$ & $x$ & $x$ & & & & [51] \\
\hline Aspergillus spp. & & & & $\mathrm{x}$ & $x$ & $\mathrm{x}$ & $x$ & $x$ & $x$ & $\mathrm{x}$ & & & [38] \\
\hline Aspergillus flavus Link & & & & $x$ & $x$ & $x$ & $x$ & $x$ & $x$ & $x$ & & & [38] \\
\hline Aspergillus niger van Tieghem & & & & & & & $x$ & $x$ & $x$ & $x$ & $x$ & $x$ & [39] \\
\hline Cladosporium cladosporioides G.A. de Vries & $\mathrm{x}$ & $x$ & $x$ & $x$ & $\mathrm{x}$ & $x$ & $x$ & $x$ & $x$ & $x$ & & & [38] \\
\hline Botrytis spp. & $\mathrm{x}$ & $x$ & $x$ & $\mathrm{x}$ & $x$ & $\mathrm{x}$ & $\mathrm{x}$ & $\mathrm{x}$ & $x$ & & & & [38] \\
\hline Colletothricum lindemuthianum Briosi e Cavara & & & & $x$ & $x$ & $x$ & $x$ & & & & & & [42] \\
\hline Fusarium oxysporum von Schlechtendal & & & & $x$ & $x$ & $x$ & $x$ & & & & & & [50] \\
\hline Fusarium solani (Mart.) Sacc. & & & & & $x$ & $\mathrm{x}$ & $x$ & $x$ & & & & & {$[50]$} \\
\hline Mucor hiemalis Wehmer & & & & & & $\mathrm{x}$ & $\mathrm{x}$ & $x$ & $\mathrm{x}$ & $\mathrm{x}$ & $x$ & $x$ & [42] \\
\hline Penicillium expansum Link & $x$ & $x$ & $\mathrm{x}$ & $x$ & $x$ & $x$ & $x$ & $x$ & & & & & [42] \\
\hline Penicillium spp. & $\mathrm{x}$ & $x$ & $\mathrm{x}$ & $x$ & $x$ & $x$ & $x$ & & & & & & [42] \\
\hline Rhizoctonia solani (Cooke) Wint. & & & & $x$ & $x$ & $x$ & $x$ & & & & & & [52] \\
\hline Rhizophus nigricans Vuillemin & & $x$ & $\mathrm{x}$ & $x$ & $x$ & $x$ & $x$ & $x$ & $x$ & & & & [50] \\
\hline Trichoderma spp. & & & & & & $x$ & $x$ & & & & & & [39] \\
\hline Uromyces appendiculatus (Pers.) Link & & & & & & $\mathrm{x}$ & $\mathrm{x}$ & $\mathrm{x}$ & & & & & [51] \\
\hline
\end{tabular}

The temperatures are indicated by the symbol $\mathrm{x}$.

For the years 2018 and 2019 the mean minimum relative humidity was $42.39 \%$ and $37.58 \%$, respectively, while the average relative humidity values were $75.09 \%$ and $71.25 \%$. These values indicate a small, but significant difference between the two years. The humidity, as well as air temperature, is important for the development of phytopathogenic fungi. In particular, xerophilic fungi prefer dry environment, where spores germinate with low relative humidity values $(<55 \%)$, as indicated in Table 6 , built in the same way of that of temperature. Aspergillus spp., A. niger and A. flavus were the xerophilic fungi detected in the current study.

Table 6. Referenced relative humidity ranges (\%) for all isolated seed-borne fungal species.

\begin{tabular}{ccccc}
\hline & \multicolumn{3}{c}{ Development Humidity (\%) } & References \\
\hline Mycoflora & $<55$ & $55<75$ & $>75$ & \\
\hline Alternaria spp. & & $\mathrm{x}$ & & {$[50]$} \\
Aspergillus spp. & & $\mathrm{x}$ & & {$[51]$} \\
Aspergillus flavus Link & $\mathrm{x}$ & & & {$[38]$} \\
Aspergillus niger van Tieghem & $\mathrm{x}$ & & & {$[38]$} \\
Alternaria alternata (Fr.) Keissler & $\mathrm{x}$ & & & {$[39]$} \\
Cladosporium cladosporioides G.A. de Vries & & & $\mathrm{x}$ & {$[38]$} \\
Botrytis spp. & & $\mathrm{x}$ & {$[38]$} \\
Colletothricum lindemuthianum Briosi e Cavara & & $\mathrm{x}$ & & {$[52]$} \\
Fusarium oxysporum von Schlechtendal & & $\mathrm{x}$ & & {$[50]$} \\
Fusarium solani (Mart.) Sacc. & & & $\mathrm{x}$ & {$[42]$} \\
Mucor hiemalis Wehmer & & $\mathrm{x}$ & {$[42]$} \\
Penicillium expansum Link & & & {$[42]$} \\
Penicillium spp. & & $\mathrm{x}$ & {$[52]$} \\
Rhizoctonia solani (Cooke) Wint. & & $\mathrm{x}$ & {$[50]$} \\
Rhizophus nigricans Vuillemin & & & {$[39]$} \\
Trichoderma spp. & & & {$[51]$} \\
\hline Uromyces appendiculatus (Pers.) Link & & & &
\end{tabular}

The relative humidities are indicated by the symbol $x$.

We found that most seed-borne isolated fungi were mesophilic with optimal growth relative humidity values between 55 and 75\%, as mentioned above, including Alternaria spp., A. alternata, C. cladosporioides, Penicillium spp., Fusarium spp., Colletotrichum spp. Among 
the hygrophilous fungi, having spores that germinate with humidity above $75 \%$, we found R. solani, Botrytis spp., and Mucor spp.

$R$. solani is a polyphagous pathogen that attacks different plant portions from the soil surface. The early symptoms are detected on the cotyledon leaves, at the base of the stem with typical dropsy areas followed by bottlenecks and brown spots on the young roots. This pathogen multiplies by repeatedly spreading its mycelium. In fact, the infections occur due to the mycelium, which is able to spread into the young tissues of the plant. The preservation of the fungus occurs in the soil as mycelium and as pseudosclerotia able to survive 6-7 years. $R$. solani has a wide distribution in temperate regions, where the optimal development temperature ranges from 15 to $22{ }^{\circ} \mathrm{C}$, with frequent rainfall [53].

The different temperature and relative humidity in the two reference years explains the different disease incidence of some seed-borne fungi. In fact, during 2018, characterized by lower maximum temperature and higher minimum and average humidity than to 2019, we recorded a greater rhizoctoniosis incidence induced by $R$. solani for both ecotypes and areas.

Anthracnose is the most severe fungal adversity of common bean. The etiological agent $C$. lindemuthianum is kept in the seed and in the soil as mycelium for up to 5 years [19]. F. oxysporum is a pathogen perpetuated in the soil, where it is kept for several years thanks to the chlamydospores [24]. The development of these two pathogens, mesophilic species, is affected by high rainfall and humidity. For this reason, it is possible also for anthracnose and fusariosis to explain the higher incidence of the disease in the year 2019 compared to the previous one as being due to the lower humidity.

In addition, concerning the incidence of anthracnose by C. lindemuthianum, of fusariosis by F. oxysporum and of bacteriosis, the results highlighted that the "Cannellino rosso" ecotype was less susceptible to plant diseases compared to the "Ciuoto" one. The reasons are to be found not only in the higher integumental thickness of "Cannellino rosso" with respect to others local ecotypes [12,54], but probably also in the higher content of polyphenolic compounds (hydrolysable tannins and condensed tannins) present in the integument, which are considered protective factors for the seed against seed-borne pathogens [55-57] and also considered potentially able to constitute a defense mechanism against fungal attack and mycotoxin production in beans [58]. Conversely, only the $\mathrm{Na}$-hypochlorite treatment induced less susceptibility to rhizoctoniosis by R. solani in the "Cannellino rosso" ecotype.

\section{Conclusions}

The phytosanitary screening of seeds of "Fagioli di Sarconi" PGI common bean ecotypes "Ciuoto" and "Cannellino rosso", cultivated in the areas of Paterno and Sarconi in the Agri Valley, made it possible to detect the fungal and bacterial microflora harmful to the quality of the seeds. It was possible to individuate the "Cannellino rosso" as being less susceptible to the majority of diseases caused by the fungi and bacteria identified. Moreover, the incidence of the pathogens analyzed in the current study was area-, environmentand ecotype-dependent. Data on seed health with respect to different common bean cultivars, meteorological conditions or cultivation location are missing. Therefore, the present study represents baseline information for further disease resistance breeding studies, development of forecasting models and management of seed-borne diseases associated with common beans.

Author Contributions: Conceptualization, M.N. and V.B.; methodology, M.N., A.V., V.B. and G.L.; formal analysis, M.N., G.L., A.V. and V.B.; investigation, G.L., S.M., T.G., V.B. and M.N.; resources, T.G., M.N. and G.L.; writing—original draft preparation, A.V., V.B., M.N. and G.L.; writing—review and editing, A.V., V.B., M.N., G.L. and T.G.; supervision, M.N.; funding acquisition, G.L. and T.G.; project administration, G.L. All authors have read and agreed to the published version of the manuscript. 
Funding: This research was financially supported by a grant from PSR Basilicata 2014/2020 -Sottomisura 10.2 "Conservazione e uso sostenibile delle risorse genetiche in agricoltura" project: PHAS.G.Re.En-Conservazione e Uso Sostenibile di Risorse Genetiche di Fagiolo (Phaseolus vulgaris L.) Lucano. DGR n.277 del 04/04/2017 n.00382520427.

Data Availability Statement: The data presented in this study are available on request from the corresponding author.

Acknowledgments: The authors are grateful to the technician Michele Palumbo for his relevant help during the activities.

Conflicts of Interest: The authors declare no conflict of interests.

\section{References}

1. Celmeli, T.; Sari, H.; Canci, H.; Sari, D.; Adak, A.; Eker, T.; Toker, C. The Nutritional Content of Common Bean (Phaseolus vulgaris L.) Landraces in Comparison to Modern Varieties. Agronomy 2018, 8, 166. [CrossRef]

2. Alvi, G. I Legumi da Granella: 2016 anno Internazionale dei Legumi; Ministero delle Politiche Agricole e Forestali: Rome, Italy, 2016; pp. 1-21.

3. Murube, E.; Beleggia, R.; Pacetti, D.; Nartea, A.; Frascarelli, G.; Lanzavecchia, G.; Bellucci, E.; Nanni, L.; Gioia, T.; Marciello, U.; et al. Characterization of Nutritional Quality Traits of a Common Bean Germplasm Collection. Foods 2021, 10, 1572. [CrossRef]

4. Graham, B.R.; Ranalli, P. Common bean (Phaseolus vulgaris L.). Field Crop. Res. 1997, 53, 131-146. [CrossRef]

5. Gioia, T.; Logozzo, G.; Attene, G.; Bellucci, E.; Benedettelli, S.; Negri, V.; Papa, R.; Spagnoletti Zeuli, P. Evidence for introduction bottleneck and extensive inter-gene pool (Mesoamerica $\mathrm{x}$ Andes) hybridization in the European common bean (Phaseolus vulgaris L.) germplasm. PLoS ONE 2013, 8, e75974. [CrossRef] [PubMed]

6. Bitocchi, E.; Rau, D.; Bellucci, E.; Rodriguez, M.; Murgia, M.L.; Gioia, T.; Santo, D.; Nanni, L.; Attene, G.; Papa, R. Beans (Phaseolus ssp.) as a Model for Understanding Crop Evolution. Front. Plant. Sci. 2017, 8, 722. [CrossRef]

7. Istituto Nazionale di Statistica. 2021. Available online: http:/ / dati.istat.it/Index.aspx?DataSetCode=DCSP_COLTIVAZIONI (accessed on 10 August 2021).

8. Piergiovanni, A.R.; Laghetti, G. The common bean land-races from Basilicata (Southern Italy): An example of integrated approach applied to genetic resources management. Genet. Resour Crop. Evol. 1999, 46, 47-52. [CrossRef]

9. Masi, P.; Logozzo, G.; Donini, P.; Spagnoletti Zeuli, P. Analysis of genetic structure in widely distributed common bean (Phaseolus vulgaris L.) landraces with different plant growth habit using SSR and AFLP markers. Crop. Sci. 2009, 49, 187-199. [CrossRef]

10. Bianco, G.; Buchicchio, A.; Cataldi, T.R.I. Structural characterization of major soyasaponins in traditional cultivars of Fagioli di Sarconi beans investigated by high-resolution tandem mass spectrometry. Anal. Bioanal Chem. 2015, 407, 6381-6389. [CrossRef]

11. Masi, P.; Figliuolo, G.; Spagnoletti Zeuli, P.L. Landraces of bean (Phaseolus vulgaris L.) collected in Basilicata, Italy. Plant. Genet. Res. Newslett. 1999, 119, 51-55.

12. Piergiovanni, A.R.; Cerbino, D.; Brandi, M. The common bean populations from Basilicata (Southern Italy). An evaluation of their variation. Genet. Resour. Crop. Evol. 2000, 47, 489-495. [CrossRef]

13. Lioi, L.; Piergiovanni, A.R.; Pignone, D.; Puglisi, S.; Santantonio, M.; Sonnante, G. Genetic diversity of some surviving on-farm Italian common bean (Phaseolus vulgaris L.) landraces. Plant. Breed. 2005, 124, 576-581. [CrossRef]

14. Dinelli, G.; Sonetti, A.; Minelli, M.; Marotti, I.; Catione, P.; Mazzanti, A. Content of flavonols in Italian bean (Phaseolus vulgaris L.) ecotypes. Food Chem. 2006, 99, 105-114. [CrossRef]

15. Piergiovanni, A.R.; Lioi, L. Italian Common Bean Landraces: History, Genetic Diversity and Seed Quality. Diversity 2010, 2, 837-862. [CrossRef]

16. Marotti, I.; Dinelli, G.; Bregola, V.; Bosi, S. Nutritional characterization of Italian common bean landraces (Phaseolus vulgaris L.): Fatty acid profiles for "genotype-niche diversity" fingerprints. AIMS Agric. Food 2020, 5, 543-562. [CrossRef]

17. Lo Cantore, P.; Nigro, C.; Castoro, V.; Iacobellis, N.S. Presenza e diffusione delle batteriosi in coltivazioni di fagiolo di Sarconi in Basilicata. J. Plant. Pathol. 2004, 89, 43-44.

18. Ghangaokar, N.M.; Kshirsagar, A.D. Study of seed borne fungi of different legumes. Trends Life Sci. 2013, 2, 32-35.

19. Marcenaro, D.; Valkonen, J.P.T. Seedborne Pathogenic Fungi in Common Bean (Phaseolus vulgaris cv. INTA Rojo) in Nicaragua. PLOS ONE 2016, 11, 1-18. [CrossRef]

20. Hussain, S.; Ajaib, M.; Asghar, R.; Ali, I.; Siddiqui, M.F. Mycoflora associated with Phaseolus vulgaris L. seeds and its impact on seed germination in Azad Jammu \& Kashmir. Pak. J. Bot. 2020, 52, 1455-1463.

21. Singh, S.R.; Singh, N.I. Seed mycoflora of broad bean and its control. Indian Phytopathol. 1986, 39, 541-543.

22. Kator, L.; Ogo-Oluwa, A.T.; Kemi, A.B. Isolation and Identification of Seed Borne Fungi of Common Bean (Phaseolus vulgaris L.) from Selected Markets in Makurdi. Int. J. Appl Agric. Sci. 2016, 2, 75-78. [CrossRef]

23. Al-Jaradi, A.; Al-Mahmooli, I.; Janke, R.; Maharachchikumbura, S.; Al-Saady, N.; Al-Sadi, A.M. Isolation and identification of pathogenic fungi and oomycetes associated with beans and cowpea root diseases in Oman. PeerJ 2018, 6, e6064. [CrossRef] 
24. Díaz, G.A.; Cabeza, R.; Amigo, R.; Llancamil, E.; Montenegro, O.; Gonzalez, P.; Valdez, A.V.; Lolas, M.A.; Ferrada, E. Severe outbreak of Fusarium wilt on common beans (Phaseolus vulgaris) caused by Fusarium oxysporum in the Maule Region, central Chile. Plant. Dis. 2021, 3. [CrossRef]

25. Gargouri, S.; Hajlaoui, M.R.; Abdennadher, M.; Marrakchi, M. Isolation and morphological and identification of Fusarium spp Transmitted by watermelon seeds. Bull. OEPP/EPPO Bull. 2000, 30, 217-222. [CrossRef]

26. Singh, D.; Mathur, S.B. Location of fungal hyphae in seeds. In Histopathology of Seed-Borne Infections, 1st ed.; Singh, D., Mathur, S.B., Eds.; CRC Press: Boca Raton, FL, USA, 2004; pp. 101-168. [CrossRef]

27. Francl, L.J. The Disease Triangle: A plant pathological paradigm revisited. Plant. Health Instr. 2001. [CrossRef]

28. Al-Askar, A.A.; Ghoneem, K.M.; Rashad, Y.M.; Abdulkhair, W.M.; Hafez, E.E.; Shabana, Y.M.; Baka, Z.A. Occurrence and distribution of tomato seed-borne mycoflora in S audi A rabia and its correlation with the climatic variables. Microb. Biotechnol. 2014, 7, 556-569. [CrossRef]

29. Juroszek, P.; Racca, P.; Link, S.; Farhumand, J.; Kleinhenz, B. Overview on the review articles published during the past 30 years relating to the potential climate change effects on plant pathogens and crop disease risks. Plant. Pathol. 2020, 69, 179-193. [CrossRef]

30. Crop Ontology for Agricultural Data. Available online: https://www.cropontology.org/terms/CO_335:0000149/ (accessed on 15 April 2019).

31. Cortinovis, G.; Opperman, M.; Neumann, K.; Graner, A.; Gioia, T.; Marsella, M.; Alseekh, S.; Fernie, A.R.; Papa, R.; Bellucci, E.; et al. Towards the Development, Maintenance, and Standardized Phenotypic Characterization of Single-Seed-Descent Genetic Resources for Common Bean. Curr. Protoc. 2021, 1, e133. [CrossRef]

32. Misra, J.K.; Mew, T.W. A Manual of Rice Seed Healt Tasting; International Rice Research Institute (IRRI): Los banõs, Laguna, Philippines, 1994.

33. International Seed Testing Association. International Rules for Seed Testing 2020: Introduction to the ISTA Rules Chapters 1-19: Including Changes and Editorial Corrections Adopted at the Ordinary General Meeting 2019, Hyderabad, India; International Seed Testing Association: Bassersdorf, Switzerland, 2020.

34. Miles, S.R. Handbook of tolerances and of measures of precision for seed testing. Proc. Int. Seed Test. Assoc. 1963, $28,525-686$.

35. Ainsworth, G.C. Introduction and keys to higher taxa. In The Fungi: An advanced Treatise IVB. A Taxonomic Review with Keys: Basidiomycetes and Lower Fungi, 1st ed.; Ainsworth, G.C., Sparrow, F.K., Sussman, A.S., Eds.; Academic Press: New York, NY, USA, 1973; pp. 1-7.

36. Kulshrestha, D.D.; Mathur, S.B.; Neergard, P. Identification of seed borne species of Colletotrichum. Friesia 1976, 11, 116-125.

37. Domsch, K.H.; Gams, W.; Anderson, T.H. Compendium of Soil Fungi, 1st ed.; IHW-Verlag: Eching, Germany, 1993.

38. Dragoni, I.; Cantoni, C.; Papa, A.; Vallone, L. Muffe, Alimenti e Micotossicosi; Città Studi Edizioni: Milano, Italy, $2000 ;$ p. 318.

39. Nipoti, P.; Fantino, M.G.; Filippini, G.; Gennari, S.; Di Pillo, L. Testo-Atlante dei Funghi ad Habitat Terricolo; Zanichelli: Bologna, Italy, 2006; p. 153.

40. Watanabe, T. Pictorial Atlas of Soil and Seed Fungi: Morphologies of Cultured Fungi and Key to Species, 3rd ed.; CRC Press: London, UK, 2010; p. 486.

41. Vannacci, G.; Sarrocco, S.; Porta-Puglia, A. Improved Detection and Monitoring of Seed-Borne Fungal Plant Pathogens in Europe. In Plant Pathology in the 21st Century: Global Perspectives on the Healthof Seeds and Plant Propagation Material; Gullino, M.L., Munkvold, G., Eds.; Springer: Dordrecht, The Netherlands, 2014; Volume 6, pp. 67-85. [CrossRef]

42. Webster, J.; Weber, R. Introduction to Fungi, 3rd ed.; Cambridge University Press: London, UK, 2016 ; p. 841.

43. SAS OnDemand for Academics. Available online: https://www.sas.com/it_it/software/on\$-\$demand\$-\$for\$-\$academics.html (accessed on 25 July 2021).

44. RStudio Core Team. RStudio: Integrated Development for R. RStudio, PBC, Boston. 2019. Available online: https://www.rstudio. $\mathrm{com} /$ (accessed on 25 July 2021).

45. Bevilacqua, V.; Vitti, A.; Logozzo, G.; Marzario, S.; Gioia, T.; Nuzzaci, M. Influence of Cultivation Areas on the Seed-Borne Pathogens on Two Local Common Bean Ecotypes of "Fagioli di Sarconi" PGI (Phaseolus vulgaris L.). Biol. Life Sci. Forum 2020, 1, 15. in press.

46. Kumar, R.; Gupta, A. Seed-Borne Disease of Agricultural Crops: Detection, Diagnosis e Management; Kumar, R., Gupta, A., Eds.; Springer Nature: Singapore, 2020. [CrossRef]

47. Harman, G.E.; Howell, C.R.; Viterbo, A.; Cett, I.; Lorito, M. Trichoderma species-opportunistic, avirulent plant symbionts. Nat. Rev. Microbiol. 2004, 2, 43-56. [CrossRef] [PubMed]

48. Vitti, A.; La Monaca, E.; Sofo, A.; Scopa, A.; Cuypers, A.; Nuzzaci, M. Beneficial effects of Trichoderma harzianum T-22 in tomato seedlings infected by Cucumber Mosaic Virus (CMV). Biocontrol 2015, 60, 135-147. [CrossRef]

49. Vitti, A.; Pellegrini, E.; Nali, C.; Lovelli, S.; Sofo, A.; Valerio, M.; Scopa, A.; Nuzzaci, M. Trichoderma harzianum T-22 Induces Systemic Resistance in Tomato Infected by Cucumber mosaic virus. Front. Plant. Sci. 2016, 7, 1-11. [CrossRef]

50. Domsch, K.H.; Gams, W.; Anderson, T.H. Compendium of Soil Fungi, 1st ed.; Academic Press: London, UK, 1980.

51. Ponti, I.; Laffi, F. Malattie crittogamiche delle piante ortive. In Schede Fitopatologiche; L'Informatore Agrario: Verona, Italy, 2001; p. 289.

52. Moore, R.T. The Genera of Rhizoctonia—Like Fungi: Ascorhizoctonia, Ceratorhiza gen. nov., Epulorhiza gen. nov., Moniliopsis and Rhizoctonia. Mycotaxon 1987, 29, 91-99. 
53. Ajayi-Oyetunde, O.O.; Bradley, C.A. Rhizoctonia solani: Taxonomy, population biology and management of rhizoctonia seedling disease of soybean. Plant Pathol. 2018, 67, 3-17. [CrossRef]

54. Disciglio, G.; Nardella, E.; Gatta, G.; Giuliani, M.M.; Tarantino, A. Adaptability of 'Monti Dauni' Bean Ecotypes in Plain Areas. WASET 2014, 8, 1118-1162.

55. Carbonaro, M.; Cappelloni, M.; Nicoli, S.; Lucarini, M.; Carnovale, E. Solubility Digestibility relationship of legume proteins. J. Agric. Food Chem 1997, 45, 3387-3394. [CrossRef]

56. Lattanzio, V.; Lattanzio, V.M.T.; Cardinali, A. Role of phenolics in the resistance mechanisms of plants against fungal pathogens and insects. In Adv Phytochem; Imperato, F., Ed.; Research Signpost Publisher: Kerala, India, 2006; pp. $23-67$.

57. Wallis, C.M.; Galarneau, E.R.A. Phenolic Compound Induction in Plant-Microbe and Plant-Insect Interactions: A Meta-Analysis. Front. Plant. Sci. 2020, 11, 580753. [CrossRef] [PubMed]

58. Telles, A.C.; Kupski, L.; Furlong, E.B. Phenolic compound in beans as protection against mycotoxins. Food Chem 2017, 214, 293-299. [CrossRef] 